Леонід Олійник, кандидат педагогічних наук, старший науковий співробітник, Національний університет оборони України імені Івана Черняховського, м. Київ ORCID ID 0000-0002-7375-1281Л.В. DOI: $10.33099 / 2617-1775 / 2021-01 / 203-211$

\title{
КОНЦЕПТУАЛЬНІ ЗАСАДИ УПРАВЛІННЯ ЯКІСТЮ НАВЧАЛЬНОӤ ДІЯЛЬНОСТІ МАГІСТРАНТІВ ВІЙСЬКОВО-СОЦІАЛЬНОГО УПРАВЛІННЯ В УМОВАХ УНІВЕРСИТЕТСЬКОЇ ОСВІТИ
}

В статті визначені концептуальні засади управління якістю навчальної діяльності магістрів військово-сочіального управління. Розглядається управління якістю навчальної діяльності військово-спеціальних дисциилін як одна із сучасних конщепцій розвитку військово-спечіальної компетентності магістрів військово-соиіального управління. Представлена система засобів управління якістю навчальної діяльності, яка необхідна для ефективного розвитку військово-спеціальної компетентності магістрів військовосочіального управління.

Ключові слова: управління якістю навчальної діяльністю, військово-спеціальна компетентність, магістри військово-соціального управління.

Постановка проблеми. У педагогічній науці сьогодні триває пошук нових ефективних шляхів удосконалення освітнього процесу в умовах університетської освіти. Метою сучасної вищої військової школи повинні стати забезпечення становлення цілісної особистості, цілеспрямований вияв i розвиток іiї здібностей, формування умінь і бажання навчатися протягом усього життя, створення умов для навчання як основи багатоступеневої військової освіти. Навчання - один із найдавніших видів людської діяльності, однак протягом усієї історії сутність цього процесу залишається незмінною, виявляючись у взаємодії викладача й слухача. Цей процес нерозривно пов'язаний з поняттям “управління”. Досягнення поставленої мети в процесі навчання, формування всебічно розвиненої особистості безпосередньо залежать від управління цим процесом. Визначений процес проходить шляхом розвитку військово-спеціальної компетентності майбутнього магістра військовосоціального управління, ефективність якого залежить від використання сучасної концепції управління якістю навчальної діяльності слухачів в умовах університетської освіти.

Аналіз досліджень і публікацій. Концептуальні засади управління якістю навчальної діяльності, що визначають цільові, змістовні та процесуальні характеристики військово-спеціальних дисциплін взагалі і розвиток військовоспеціальної компетентності зокрема, розкриті в дослідженнях багатьох вчених - I. Блощинського [1], О. Торічного [10], В. Ягупова [11] та інших.

Аналіз досліджень [4; 7] показує, що проблему ефективної організації освітнього процесу остаточно не розв'язано. У наш час розгляд процесу 
навчання в умовах університетської освіти як процесу управління $є$ вельми продуктивним, проте, як показують дослідження в цій сфері, багато теоретичних і практичних питань залишаються відкритими. Теорія управління вимагає глибокого вивчення й аналізу з метою визначення ii дидактичних можливостей і практичної значущості.

Метою статті $\epsilon$ визначення концептуальних засад управління якістю навчальної діяльності магістрантів військово-соціального управління в умовах університетської освіти.

Виклад основного матеріалу. Навчальна діяльність представляє процес, в результаті якого магістрант військово-соціального управління набуває нові або змінює існуючі у нього знання, уміння, навички, удосконалює і розвиває свої здібності. Навчання - спільна навчальна діяльність науково-педагогічного працівника та слухача, в процесі якої проходить передача знань, умінь та навичок, життєвого досвіду. Управління передбачає управляючі впливи та отримання від слухачів через зворотній зв'язок інформації про стан навчальної діяльності майбутнього магістра військово-соціального управління та пі1 результатів. I науково-педагогічний працівник i магістрант військовосоціального управління як особистості є суб'єктами діяльності, спілкування. Кожен з них є суб’єктом предметної діяльності, суб’єктом самосвідомості. Таким чином, науково-педагогічний працівник - суб'єкт педагогічної діяльності, а слухач - суб'єкт навчальної діяльності. Управління якістю навчальної діяльності слухачів здійснюється за допомогою певних дій, що задаються заздалегідь (контроль - корекція). При управлінні відбувається постійний контроль за ходом процесу навчання і за необхідності його корекція. Прикладом визначеного управління може бути опитування слухачів науковопедагогічним працівником i негайне роз'яснення помилок у засвоєнні навчального матеріалу. У цьому разі існує прямий і зворотний зв'язок 3 викладачем, який значно поліпшує якість засвоєння.

Одним із видів управління можна вважати проблемне навчання. За допомогою прямого управління (питань викладача) здійснюється перехід до співуправління, а потім і до самоуправління слухача. Педагогічна ситуація скеровує розумову діяльність на розв'язання проблеми; робота в процесі розв'язання проблеми - дуже важливий етап, іноді навіть важливіший ніж саме розв'язання. Формування особистості, що здатна творчо мислити, знаходити рішення неординарним шляхом, це мета, яку ставить перед собою викладач при переході слухачів на рівень самоуправління. Проблемні ситуації викликають у слухачів необхідність вивчати новий теоретичний і практичний матеріал; вони створюють умови для поглибленого розуміння цілей і змісту навчання. Головним компонентом даного типу навчання є особистість слухача 3 iii здібностями, психофізіологічними особливостями, а також індивідуальний підхід до нього. Науково-педагогічний працівник виступає організатором діяльності магістрантів військово-соціального управління i розвиває їхню мотивацію до навчання, творчу активність.

Процес навчання військово-спеціальних дисциплін магістрів військовосоціального управління має бути підпорядкованим не стільки завданню 
інформаційного насичення, скільки формуванню продуктивного мислення, розвитку інтелектуального потенціалу особистості, становленню способів логічного аналізу і всебічної обробки інформації, творчому конструюванню [8, c. 108].

Якісне навчання військово-спеціальних дисциплін магістрів військовосоціального управління забезпечує та педагогічна технологія, яка передбачає систематичне діагностування готовності слухачів до навчальних занять, своєчасну корекцію рівня військово-спеціальної компетентності та періодичний контроль за роботою всіх учасників освітнього процесу. А це пов'язано 3 виконанням таких вимог:

забезпечення ефективних психолого-педагогічних умов для суб'єктів освітнього процесу;

створення сприятливого педагогічного середовища; створення належної організації різних видів начальної праці в навчальний та поза навчальний час у відповідності 3 методичними рекомендаціями засобами функціонування обраної моделі технології навчання;

додержання логічної послідовності у вивченні навчального матеріалу (модулі, розділи, теми тощо);

мотивація до вивчення фахового навчального матеріалу; забезпечення доступності в навчанні та обов'язкової орієнтації на фаховий профіль вищого військового навчального закладу [5, с. 124].

Особливого значення набуває проблема визначення управління якістю навчальної діяльності магістрантів військово-соціального управління в умовах університетської освіти, що конкретизує відповідні принципи і має характер практичних вказівок, якими слід безпосередньо керуватися при відбиранні i концентрації навчального матеріалу за спеціалізаціями "Організація моральнопсихологічного забезпечення військ (сил)", “Організація психологічного забезпечення військ (сил)", "Інформаційно-пропагандистське забезпечення військ (сил) та ідеологічна робота у військах" спеціальності 254 "Забезпечення військ (сил)". При цьому зазначимо, що будь-який принцип оцінюють, насамперед, як елемент науково-педагогічного знання, 3 огляду на його методологічно-евристичні функції та виконання ним регулятивних функцій у будь-якому процесі.

Активізація навчальної діяльності магістрантів забезпечується виконанням цілої системи психолого-педагогічних умов, а саме: чіткого визначення цілей освітнього процесу, їх усвідомлення науково-педагогічними працівниками i слухачами, приведенням у відповідність до цілей змісту навчання, введенням такої методики навчання, яка створила б максимальні можливості для прояву ініціативи, самостійності і творчості особистості, забезпеченням якісного контролю за навчально-пізнавальною діяльністю слухачів. Удосконалення процесу навчання залежить від умінь науково-педагогічного працівника планувати, організовувати, цілеспрямовано управляти пізнавальною діяльністю та активізувати іiі. Складовими успіху при цьому є: опора на психологопедагогічні знання і особливості освітнього процесу; поєднання у методиці викладання (навчання) основ психології і дидактики; створення власної 
методики на основі використання закономірностей системи психологічних i дидактичних знань [2, с. 125-126].

Управління якістю навчальної діяльності магістрантів військовосоціального управління - це така форма організації освітнього процесу педагогом, яка націлена на конкретний результат - оволодіння слухачем професійними знаннями, уміннями та навичками; ефективність даного процесу забезпечується зворотним зв'язком на всіх етапах навчальної діяльності магістрантів військово-соціального управління. Ефективність управління якістю навчальної діяльності магістрантів військово-соціального управління безпосередньо залежить від засобів, застосовуваних в освітньому процесі; отже, дидактичні засоби можуть розглядатись як засоби управління навчальною діяльністю слухачів. Функції управлінської діяльності (проектування, організація, керівництво, контроль i корекція) мають загальний характер i повинні застосовуватися до процесу навчання 3 метою підвищення розвиненості військово-спеціальної компетентності магістрантів військовосоціального управління.

Ефективна система управління освітою має містити: чіткі цільові настанови; процеси планування (проектування); запровадження інноваційних інформаційно-комунікаційних технологій; всебічного кадрового, матеріальнотехнічного, фінансового, дидактичного, інформаційного, психологічного, санітарно-гігієнічного забезпечення; контроль; моніторинг; коригування повинно бути спрямовано на досягнення кінцевого результату - якісну підготовку військових фахівців [9, с. 73].

Управління якістю навчальної діяльності магістрантів військовосоціального управління як засіб ефективного розвитку військово-спеціальної компетентності слухача досягається шляхом: формування мети навчання; розробки програми дій, що передбачає основні перехідні стани процесу навчання; отримання даних по певним параметрам про стан процесу навчання (зворотній зв’язок); переробки інформації, отриманої по каналу зворотного зв’язку, відпрацювання і внесення в управління якістю навчальної діяльності магістрантів військово-соціального управління корекції

В основу концептуальних засад управління якістю навчальної діяльності магістрантів військово-соціального управління в умовах університетської освіти покладено такі положення:

управління якістю навчальної діяльності магістрантів військовосоціального управління в умовах університетської освіти $\epsilon$ складовою неперервної педагогічної освіти, зумовленої соціально-економічними чинниками розвитку суспільства, що враховує сучасні тенденції, вітчизняний i зарубіжний досвід підготовки магістрів, відображає специфіку магістерської підготовки (зміст, форми, методи i педагогічні технології), передбачає створення дієвих стимулів професійного та особистісного розвитку магістра військово-соціального управління на основі моніторингу якості реалізації освітніх стандартів;

управління якістю навчальної діяльності магістрантів військовосоціального управління в умовах університетської освіти розглядається як 
науково обгрунтована система суб'єкт-суб' єктної взаємодії, в основу побудови якої покладено принцип компетентісного підходу. Теоретичними основами побудови концепції управління якістю навчальної діяльності магістрантів військово-соціального управління є сучасні освітні парадигми (антропологічна, гуманістична, гуманітарна, культурологічна), концепції (лідерства, освіта впродовж життя, особистісно орієнтована освіта) та компетентнісний підхід;

система управління якістю навчальної діяльності магістрантів військовосоціального управління в умовах університетської освіти трактується як різновид педагогічної системи, оскільки вона має всі ознаки, властиві такій системі: слугує основою теоретичного осмислення і побудови психологопедагогічної діяльності; включає певну сукупність взаємопов'язаних засобів, методів і процесів, необхідних для створення організованого, цілеспрямованого педагогічного впливу на розвиток особистості із заданими якостями; забезпечує виконання ціннісно-змістових, нормативних, технологічних і процесуальнорезультативних функцій психолого-педагогічної діяльності; сприяє досягненню поставлених цілей розвитку людини;

системотворчими елементами управління якістю навчальної діяльності магістрантів військово-соціального управління в умовах університетської освіти є: загальнолюдські цінності, мета, завдання та особливості науковопедагогічної діяльності, закономірності й принципи навчання слухачів. Змінними складовими є: організаційно-педагогічні умови здійснення освітнього процесу (зміст, форми, технології його організації, умови кадрового, фінансовоматеріального i науково-методичного забезпечення, методика діагностики, результативність). Управління якістю навчальної діяльності магістрантів військово-соціального управління спрямовується на розвиток їх військовоспеціальної компетентності. Досягнення цієї мети можливе за умови реалізації в освітньму процесі системи принципів, що визначають цілі й зміст навчання майбутніх магістрів військово-соціального управління, розкривають особливості удосконалення науково-педагогічної діяльності [3, с. 125-126].

Управління якістю навчальної діяльності майбутніх магістрів військовосоціального управління включає:

мотиваційно-цільову складову, метою якої є надання можливості слухачам виробити власну траєкторію навчання виходячи 3 мотивів набуття військовоспеціального досвіду з метою послідовного опанування військово-спеціальною компетентністю;

змістову складову, яка визначає досвід розвитку військово-спеціальної компетентності за рахунок варіативності навчання військово-спеціальних дисциплін, що забезпечує пізнавальну активність майбутніх магістрів військово-соціального управління: ситуації, ділові ігри, групові вправи, тренінги, який поповнюється досвідом набуття знань, умінь, навичок моральнопсихологічного забезпечення діяльності військ; операційно-процесуальна складова передбачає наявність наступних форм: лекції, практичні заняття, групові вправи, командно-штабні навчання, самостійна робота, військове стажування та методів: рольові ігри, ситуаційні вправи, дискусії, захист проектів, есе; 
результативна складова базується на наступних компонентах:

мотиваційно-ціннісний компонент, який має дати магістрам військовосоціального управління сукупність ціннісних орієнтацій для професійної діяльності та забезпечити усвідомлення і сприйняття ними норм і правил цієї діяльності;

когнітивний компонент має забезпечити магістрів військово-соціального управління системою військово-спеціальних знань та умінь;

особистісний компонент має сприяти самопізнанню магістра військовосоціального управління самого себе як творчої особистості, формувати його адекватну самооцінку, допомогти його професійному самовизначенню та самоактуалізації;

операційно-діяльнісний компонент має сприяти формуванню і постійному вдосконаленню у майбутніх магістрів військово-соціального управління творчих методів, прийомів і форм професійної діяльності [6, с. 87-88].

Розгляд процесу навчання як процесу управління якістю навчальної діяльності магістрантів військово-соціального управління дає змогу ефективніше ставити завдання навчання, проектувати процес навчання i необхідні засоби, здійснювати постійну взаємодію науково-педагогічного працівника і слухача завдяки наявності зворотного зв’язку, коригувати хід процесу навчання з метою його оптимізації.

Висновки. Таким чином в основу управління якістю навчальної діяльності магістрантів військово-соціального управління $\epsilon$ ефективною за умов впровадження компетентісного підходу який дозволяє комплексно враховувати у системі навчання військово-спеціальних дисциплін вимоги військовопрофесійної діяльності та субєктно-діяльнісні особливості слухачів їх прагнення до самоактуалізації у військово-професійній діяльності офіцера морально-психологічного забезпечення.

Отже, необхідно констатувати, що основними шляхами подальшого підвищення якості навчальної діяльності магістрантів військово-соціального управління є:

покращення планування та організації освітнього процесу;

створення всебічних умов для навчання слухачів; активізація роботи щодо запровадження в освітній процес особистісно-орієнтованих, інформаційнокомунікаційних технологій;

підвищення рівня науково-методичного та матеріально-технічного забезпечення самостійної роботи магістрів військово-соціального управління 3 вивчення військово-спеціальних дисциплін, ії планування й організації;

забезпечення дієвості моніторингу якості засвоєння слухачами знань, умінь, навичок; дослідження теоретичних і практичних проблем навчальнопізнавальної діяльності слухачами, психологічних основ самоуправління засвоєнням знань.

Напрямками подальшого дослідження $\epsilon$ визначення концепції освіта впродовж життя шляхом впровадження професійної військової освіти. 


\section{ЛІТЕРАТУРА}

1. Блощинський І. Г. Теорія та практика професійної підготовки фахівців Державної прикордонної служби України 3 використанням технологій дистанційного навчання : [моногр.] / І. Г. Блощинський. - Хмельницький : вид-во НАДПСУ, 2016. - 496 с.

2. Олійник Л. В. Активізація навчально-пізнавальної діяльності магістрантів в системі вищої військової школи / Л.В. Олійник Збірник наукових праць “Військова освіта”. - № 2 (40). - 2019. - C. 128-138.

3. Олійник Л. В. Концептуальні засади навчання військово-спеціальних дисциплін магістрів військово-соціального управління / Л.В. Олійник Науковий вісник Чернівецького університету: Збірник наукових праць. - Вип. 679. Педагогіка та психологія. - 2014. - С. $124-133$.

4. Олійник Л. В. Методична система навчання військово-спеціальних дисциплін магістрів військово-соціального управління : [монографія] / Леонід Віталійович Олійник. Хмельницький : Видавництво НАДПСУ, 2017. - 340 с.

5. Олійник Л. В. Методичні засади навчання військово-спеціальних дисциплін магістрів військово-соціального управління / Л.В. Олійник. Вісник Національного університету України - № 3 (40). - 2014. - С. 122-127.

6. Олійник Л. В. Модель управління навчальною діяльністю майбутніх магістрів військово-соціального управління / Л.В. Олійник Наукові праці ДонНТУ. Серія: «Педагогіка, психологія і соціологія». Всеукраїнський науковий збірник. - № 1 (20). - 2017. - C. 84-89.

7. Олійник Л. В. Основи побудови методичної системи навчання військово-спеціальних дисциплін магістрів військово-соціального управління / Л.В. Олійник. Збірник наукових праць Національної академії державної прикордонної служби України. Серія: «Педагогічні та психологічні науки» - № 4 (69). - 2013. - С. 178-190.

8. Олійник Л. В. Навчання військово-спеціальних дисциплін магістрів військовосоціального управління як науково-методична проблема / Л.В. Олійник. Вісник Національного університету України - № 6 (37). - 2013. - С. 104-109.

9. Олійник Л. В. Якість підготовки військових фахівців як результат ефективної системи управління освітою / Л.В. Олійник, О.А. Прохоров Збірник наукових праць “Військова освіта". - № 2 (32). - 2015. - С. 164-173.

10. Торічний О.В. Теоретико-методичні засади формування військово-спеціальної компетентності майбутніх офіцерів-прикордонників у процесі навчання : автореф. дис. на здобуття наук. ступеня доктора пед. наук: спец. 13.00.02 “Теорія та методика навчання (загальновійськові й військово-спеціальні дисципліни)" / О. В. Торічний. - К., 2013. - 38 с.

11. Ягупов В. В. Теорія і методика військового навчання : [монографія] / Василь Васильович Ягупов. - К : Тандем, 2000. - 380 с.

\section{REFERENCES}

1. Bloshchynskyy I. H. Teoriya ta praktyka profesiynoyi pidhotovky fakhivtsiv Derzhavnoyi prykordonnoyi sluzhby Ukrayiny $\mathrm{z}$ vykorystannyam tekhnolohiy dystantsiynoho navchannya: [monohr.] / I. H. Bloshchyns'kyy. - Khmelnytskyy: vyd-vo NADPSU, 2016. - $496 \mathrm{~s}$.

2. Oliynyk L. V. Aktyvizatsiya navchalno-piznavalnoyi diyalnosti mahistrantiv u systemi vyshchoyi viyskovoyi shkoly / L.V. Oliynyk Zbirnyk naukovykh prats "Viyskova osvita". - № 2 (40). - 2019. - S. 128-138.

3. Oliynyk L. V. Kontseptualni zasady navchannya viyskovo-spetsialnoho dystsypliny mahistriv viyskovo-sotsialnoho upravlinnya / L.V. Oliynyk Naukovyy visnyk Chernivetskoho universytetu: Zbirnyk naukovykh prats. - Vyp. 679. Pedahohika ta psykholohiya. - 2014. - S. 124133.

4. Oliynyk L. V. Metodychna systema navchannya viyskovo-spetsialnykh dystsyplin mahistriv viyskovo-sotsialnoho upravlinnya: [monohrafiya] / Leonid Vitaliyovych Oliynyk. Khmelnytskyy: Vydavnytstvo NADPSU, 2017. - 340 s. 
5. Oliynyk L. V. Metodychni zasady navchannya viyskovo-spetsialnoho dystsypliny mahistriv viyskovo-sotsialnoho upravlinnya / L.V. Oliynyk. Visnyk Natsionalnoho universytetu Ukrayiny - № 3 (40). - 2014. - S. 122-127.

6. Oliynyk L. V. Model upravlinnya navchalnoyu diyalnistyu maybutnikh mahistriv viyskovo-sotsialnoho upravlinnya / L.V. Oliynyk Naukovi pratsi DonNTU. Seriya: «Pedahohika, psykholohiya ta sotsiolohiya». Vseukrayinskyy naukovyy zbirnyk. - № 1 (20). - 2017. - S. 84-89.

7. Oliynyk L. V. Osnovy pobudovy metodychnoyi systemy navchannya viys'kovospetsialnoho dystsypliny mahistriv viyskovo-sotsialnoho upravlinnya / L.V. Oliynyk. Zbirnyk naukovykh prats Natsionalnoyi akademiyi derzhavnoyi prykordonnoyi sluzhby Ukrayiny. Seriya: «Pedahohichni ta psykholohichni nauky» - № 4 (69). - 2013. - S. 178-190.

8. Oliynyk L. V. Navchannya viyskovo-spetsialnoho dystsypliny mahistriv viyskovosotsialnoho upravlinnya yak naukovo-metodychna problema / L.V. Oliynyk. Visnyk Natsional'noho universytetu Ukrayiny - № 6 (37). - 2013. - S. 104-109.

9. Oliynyk L. V. Yakist pidhotovky viyskovykh fakhivtsiv yak rezultat efektyvnoyi systemy upravlinnya osvitoyu / L.V. Oliynyk, O.A. Prokhorov Zbirnyk naukovykh prats "Viyskova osvita". - № 2 (32). - 2015. - S. 164-173.

10. Torichnyy O.V. Teoretyko-metodychni zasady formuvannya viyskovo-spetsialnoyi kompetentnosti maybutnikh ofitseriv-prykordonnykiv $\mathrm{v}$ protsesi navchannya: avtoref. dys. na zdobuttya nauk. stupenya doktora ped. nauk: spets. 13.00.02 "Teoriya ta metodyka navchannya (zahalnoviyskovi y viyskovo-spetsialni dystsypliny)" / O. V. Torichnyy. - K., 2013. - 38 s.

11. Yahupov V. V. Teoriya i metodyka viyskovoho navchannya: [monohrafiya] / Vasyl Vasylovych Yahupov. - K: Tandem, 2000. - 380 s.

\section{PEЗЮМЕ}

Леонид Олейник, кандидат педагогических наук, старший научный сотрудник, Национальный университет обороны Украины имени Ивана Черняховского

\section{Концептуальные основы управления учебной деятельностью будущих магистров} военно-социального управления в условия университетского образования

В статье определены концептуальные основы управления учебной деятельностью магистров военно-социального управления. рассматривается управления учебной деятельностью как одна из концепций развития военно-специальной компетентности магистров военно-социального управления. Представлена система средств управления учебной деятельностью как необходимая для эффективного развития военно-специальной компетентности магистров военно-социального управления.

Ключевые слова: управления учебной деятельностью, военно-специальная компетентность, магистры военно-социального управления.

\section{SUMMARY}

Leonid Oliynyk, $\mathrm{PhD}$

(Candidate of pedagogical sciences, Senior research scientist) Senior research scientist of methodical and scientific center of educational activity organization of the National Defense University of Ukraine named after Ivan Chernyakhovskyi, c. Kyiv

Conceptual principles of quality control of educational activities of masters of military and social management in the university 
The article reveals conceptual principles of military and social management masters of the educational activities control. Educational activities control is considered as one of the modern conceptions of special military competence development of military and social management masters.

According to the analysis of psychological and pedagogical literature, it is determined that the main feature of modern higher education is its humanistic orientation, when the main attention is paid to the formation of a many-sided man. Consideration of the educational process as a process of quality control of educational activities of masters of military and social management allows more effectively to set learning objectives, design the learning process and the necessary tools, carry out constant interaction between research and teaching staff and students through feedback, adjust the educational process its optimization. the Quality control of educational activities of future masters of military and social management is a form of organization of the educational process by a lecturer, which is aimed at a specific result - the student's mastery of professional knowledge, skills and abilities; the effectiveness of this process is ensured by feedback at all stages of the educational activities of future masters of military and social management. The efficiency of quality control of educational activities of future masters of military and social management directly depends on the means used in the educational process; therefore, didactic tools can be considered as a means of managing the learning activities of students. The functions of management activities (design, organization, management, control and correction) are general in nature and should be applied to the training process in order to increase the development of military-special competence of future masters of military and social management.

Quality control of educational activities of future masters of military and social management is efficient in following cases:

the initial methodological principles of the research are based on the competence approach;

the content and structure of quality control of educational activities of future masters of military and social management are determined by the conceptual-theoretical model, the essential components and system-forming factors such as: professionalism of pedagogical activity (productivity and skill) and professionalism of the student's personality (ability to pedagogical creativity);

the basis for the organization of quality control of educational process of future masters of military and social management is methodological system, which is a unity of its motivationaltarget, semantic, operational-procedural and effective components, which is gradually realized in the educational process taking into account a certain set of basic approaches, directions, psychological and pedagogical conditions .

System of means and principles of the educational activities control as necessary one for effective special military competence development of military and social management masters.

Key words: educational activities control, professional training, humanization of education, special military competence, military and social management masters. 